E International

\title{
Capacity Building through Efficient Use of Existing Airport Infrastructure
}

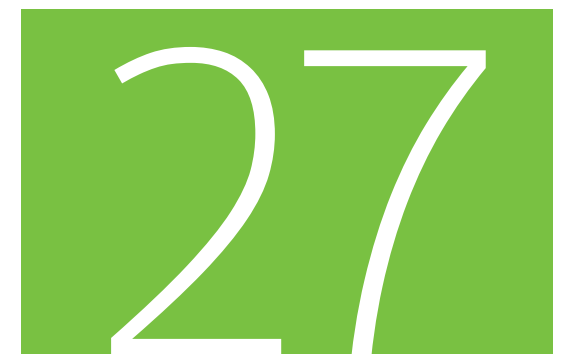

Discussion Paper 2017 • 27

Jagoda Egeland

International Transport Forum, Paris

Paul Smale

Department for Transport, United 


\title{
EInternational \\ Transport Forum
}

\section{Capacity building through Efficient Use of Existing Airport Infrastructure}

\author{
Discussion Paper No. 2017-27
}

Summary Report of the Roundtable on Capacity Building through Efficient Use of Existing Airport Infrastructure (9-10 March 2017, Querétaro)

\author{
Jagoda Egeland \\ International Transport Forum \\ Paul Smale \\ Department for Transport, United Kingdom
}

October 2017 


\title{
The International Transport Forum
}

The International Transport Forum is an intergovernmental organisation with 59 member countries. It acts as a think tank for transport policy and organises the Annual Summit of transport ministers. ITF is the only global body that covers all transport modes. The ITF is politically autonomous and administratively integrated with the OECD.

The ITF works for transport policies that improve peoples' lives. Our mission is to foster a deeper understanding of the role of transport in economic growth, environmental sustainability and social inclusion and to raise the public profile of transport policy.

The ITF organises global dialogue for better transport. We act as a platform for discussion and prenegotiation of policy issues across all transport modes. We analyse trends, share knowledge and promote exchange among transport decision-makers and civil society. The ITF's Annual Summit is the world's largest gathering of transport ministers and the leading global platform for dialogue on transport policy.

The Members of the Forum are: Albania, Armenia, Argentina, Australia, Austria, Azerbaijan, Belarus, Belgium, Bosnia and Herzegovina, Bulgaria, Canada, Chile, China (People's Republic of), Croatia, Czech Republic, Denmark, Estonia, Finland, France, Former Yugoslav Republic of Macedonia, Georgia, Germany, Greece, Hungary, Iceland, India, Ireland, Israel, Italy, Japan, Kazakhstan, Korea, Latvia, Liechtenstein, Lithuania, Luxembourg, Malta, Mexico, Republic of Moldova, Montenegro, Morocco, the Netherlands, New Zealand, Norway, Poland, Portugal, Romania, Russian Federation, Serbia, Slovak Republic, Slovenia, Spain, Sweden, Switzerland, Turkey, Ukraine, the United Arab Emirates, the United Kingdom and the United States.

\author{
International Transport Forum \\ 2 rue André Pascal \\ F-75775 Paris Cedex 16 \\ contact@itf-oecd.org \\ www.itf-oecd.org
}

\section{ITF Discussion Papers}

ITF Discussion Papers make economic research, commissioned or carried out in-house at ITF, available to researchers and practitioners. They describe preliminary results or research in progress by the author(s) and are published to stimulate discussion on a broad range of issues on which the ITF works. Any findings, interpretations and conclusions expressed herein are those of the authors and do not necessarily reflect the views of the International Transport Forum or the OECD. Neither the OECD, ITF nor the authors guarantee the accuracy of any data or other information contained in this publication and accept no responsibility whatsoever for any consequence of their use. This document and any map included herein are without prejudice to the status of or sovereignty over any territory, to the delimitation of international frontiers and boundaries and to the name of any territory, city or area. Comments on Discussion Papers are welcome. 


\section{Acknowledgements}

This discussion paper sets out the findings of an ITF Roundtable on Capacity Building through Efficient Use of Existing Airport Infrastructure, which was held on 9-10 March 2016 in Querétaro.

The discussion paper was drafted by Jagoda Egeland (ITF) and Paul Smale (Department for Transport, UK). Valuable comments on draft versions were provided by from Nicole Adler (Hebrew University of Jerusalem), Philippe Ayoun (Direction générale de l'aviation civile), Stefano Baronci (ACI World), Elliott Black (Federal Aviation Administration, USA), Guillaume Burghouwt (SEO Amsterdam Economics), Alfonso Herrera García (Instituto Mexicano del Transporte), Barry Humphreys (BKH Aviation), Alexandre Jacquillat (Carnegie Mellon University), Miguel Mujica Mota (Amsterdam University of Applied Sciences), Albert Muldoon (Department of Transportation, USA), Stephen Perkins (ITF), Mike Tretheway (InterVISTAS Consulting), Victor Hugo Valdes Cervantes (Anáhuac University), James Wiltshire (IATA), and Konstantinos Zografos (Lancaster University Management School).

The authors would like to thank Monserrat Fonbonnat, Anna Garbarczyk, Cécilia Paymon, and Bernardo Vazquez for valuable assistance with the paper. 


\begin{abstract}
This paper is based on expert discussions on how airport capacity could be improved to benefit the users of aviation, without building new airport infrastructure. These discussions took place at a Roundtable meeting of 34 experts ${ }^{1}$ held in Querétaro, Mexico in March 2017. Roundtable participants took a view that any congested airport represents a market failure with rents accruing either to airlines and/or elsewhere along the value chain. Administrative slot allocation, while it can help achieve particular connectivity outcomes, cannot allocate capacity in a market efficient way. Allocating capacity through market based instruments such as slot auctioning can achieve that goal, but it currently is both technically and politically difficult to implement without creating significant disruption to the network. The distributive impacts of slot allocation regimes and any trade-offs from potential changes to them thus need to be considered by policy makers before deciding on any capacity allocation measures. Participants agreed that a multi-faceted approach is needed to improve welfare of aviation users, which in particular needs to take advantage of technological change in the sector.
\end{abstract}




\section{Table of Contents}

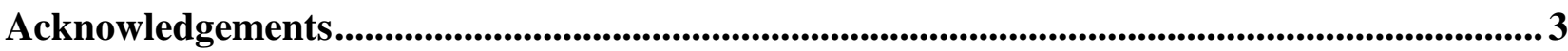

Capacity Building through Efficient Use of Existing Airport Infrastructure ...........................5

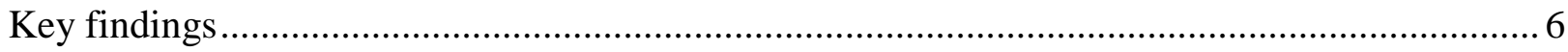

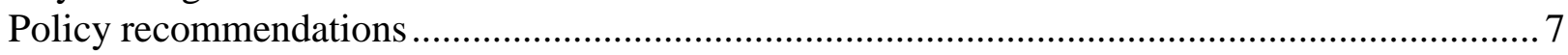

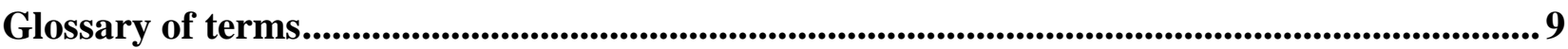

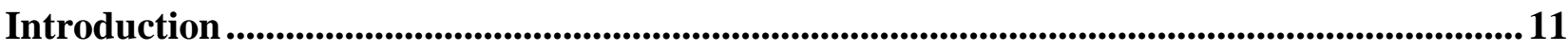

Scope

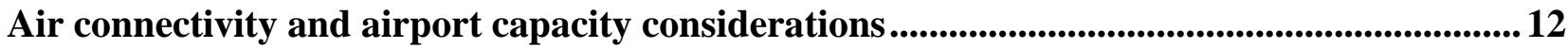

Air connectivity improvements need to be considered alongside all impacts of air transport,

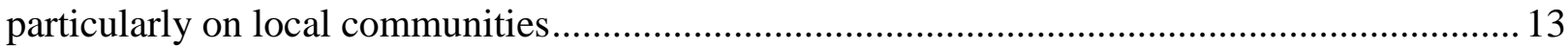

Capacity constraints can limit the development of air connectivity .......................................... 14

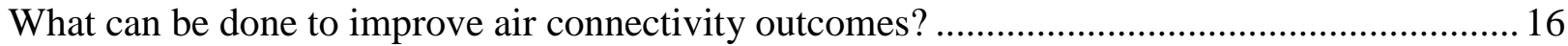

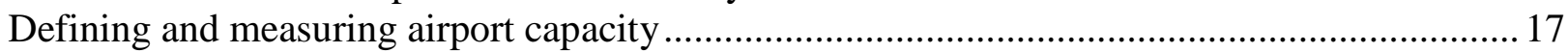

What can be done to make more efficient use of existing airport capacity? ..........................20

Relaxation of policy constraints on airport capacity due to technological improvements ..........20

Technology to improve efficiency of airports ...................................................................... 21

Policy mechanisms to make more efficient use of existing airport capacity ........................... 24

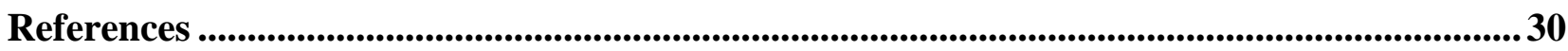

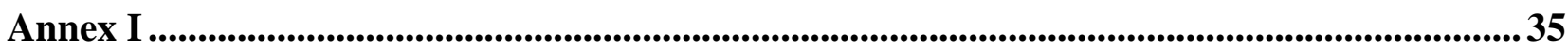

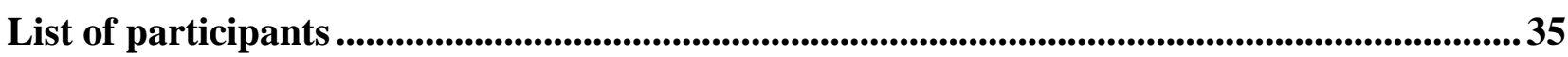

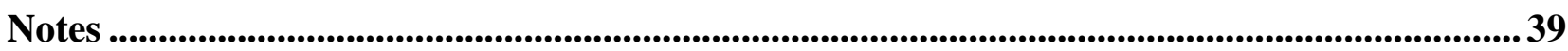




\section{Capacity Building through Efficient Use of Existing Airport Infrastructure}

\section{Key findings}

Airports, airlines, air navigation service providers, and regulators should pursue all possible technical innovations to improve utilisation of available airport capacity. Collaborative decision-making is critical to this. Improving capacity utilisation, however, is very unlikely to deal with the long-term capacity challenge at congested airports. Ultimately the only credible solution to alleviating chronic capacity constraints is through long-term planning and investment in new infrastructure.

Any airport that becomes a Worldwide Slot Guidelines (WSG) Level 32 congested airport indicates market failure. Insufficient capacity at such airports causes rents to accrue to airlines, airports and elsewhere along the value chain, which results in higher ticket prices for the users. Such airports also often suffer from delays and resilience issues.

At airports where capacity constraints are imposed by the policy-maker to reduce the adverse impacts of aviation, predominantly noise and air pollution, technological improvements can help relax constraints. Policy changes in response to innovation will incentivise the industry to improve further, for example in reducing aircraft noise.

The majority of congested airports that follow the WSG have their slots allocated to airlines by an independent slot coordinator who applies a set of administrative principles guiding the allocation. This is the system at all congested airports in Europe. But in the USA, apart from a few high-profile exceptions, congested airports do not have an administrative slot allocation mechanism imposed on them.

Slot auctions, to allocate slots to the airlines that value them most, are still very uncommon. However, there are exceptions: the Civil Aviation Administration of China tried slot auctioning in 2015 and Mexican competition law provides for a proportion of slots at the hub airport in Mexico City to be auctioned every year - a mechanism that is yet to be used in practice.

Capacity management can also be used as a tool for striking a balance between maximising available capacity and minimising the negative impacts of running close to capacity on punctuality and resilience. While managing scarce capacity through either administrative slot allocation or market-based instruments cannot increase capacity at airports, it can be used to distribute slots to those airlines that extract highest value from using the slot or to help achieve particular government policy objectives, for example increasing domestic or long-haul air connectivity or enhancing competition.

An administrative allocation of slots will always create winners and losers. In particular, grandfathering of landing rights at airports where slots are allocated to the benefit of incumbent airlines makes it difficult for new entrants to start operations when there is no prospect of significant capacity coming on-stream. Who wins and who loses from slot allocation needs to be considered carefully by policy makers from the point of view of maximising welfare for society.

Where airport capacity is managed with administrative slot allocation, the experts agreed that the IATA Worldwide Slot Guidelines have worked, albeit not perfectly. The WSG provide a mechanism that 
seeks to balance the benefits of competition and the benefits of maintaining wide route networks typical of incumbent hub carriers. Whilst the WSG aim to promote efficiency both from allocating capacity to those that can make best use of it today and reserving capacity for competitors to drive efficiency in the future, two specific weaknesses are highlighted: failure to re-allocate some of the existing capacity to new entrants; and a failure to deliver new capacity to new entrants in practice.

IATA (2017) is currently working with ACI and the Worldwide Airport Coordinators Group on a Strategic Review of the WSG, to fully take into consideration the interest of airport operators and passengers. Participants expect the Strategic Review to improve the WSG through the active participation of states, airlines, airport operators, and slot coordinators.

In terms of economic efficiency, all Roundtable participants agreed that pairing WSGs with secondary slot trading would go some way towards closing the economic efficiency gap. Some experts noted that market-based policies such as periodic withdrawal of all or a proportion of slots from incumbents and auctioning may improve economic efficiency, at the risk however of a potentially extreme disruption to airline businesses and/or the reallocation of windfall rents. The withdrawal of slots from incumbents could be particularly problematic wherever airlines have made significant investments in the airport infrastructure, such as in many airports in the USA. The Mexican approach of reallocating only a proportion of slots each year could avoid such severe disruption.

In addition to the levers mentioned above, some experts argued that peak pricing should be considered as a policy option to incentivise the smoothing of demand peaks throughout the operating day and to reward larger aircraft sizes. This was seen as potentially useful notwithstanding the fact that the few examples of peak pricing of slots experimented with to date did not produce the desired outcomes.

Airlines are often penalised for using large aircraft through weight-based landing fees at congested airports, which can result in higher per capita fees for large aircraft. This fee structure originates in revenue generating price discrimination, appropriate for smaller, uncongested airports but counterproductive in congested airports.

\section{Policy recommendations}

- Whilst governments should act cautiously and avoid intervention unless there are strong reasons for it, airports, airlines, air navigation service providers, and regulators need to pursue all possible technical innovations to improve the utilisation of airport capacity. Collaborative decision-making is critical to achieving optimal outcomes.

- Governments should consider policies improving air connectivity alongside all impacts of air transport, in particular in terms of noise and air pollution impacts on local communities.

- Governments should constantly re-evaluate caps on aircraft movements that are designed to contain noise impacts, as technological improvements make it possible to reduce noise nuisance while allowing for more aircraft operations.

- IATA WSG should continue to evolve to facilitate more efficient use of scarce airport capacity, ultimately benefitting passengers and other users of aviation. Authorities should ensure that the rules are applied in practice as intended. 
- Any system of slot allocation at congested airports needs to take account of the potential benefits of competition. When slots are allocated to new entrants they should be in sufficient quantity to support viable business models.

- The potential to use primary slot auctioning to improve welfare outcomes at congested airports should not be ruled out. To make decisions on primary slot auctioning, the transfer of rents needs to be considered explicitly, and steps taken to avoid excessive disruption to incumbent airlines.

- Secondary slot trading should be allowed and facilitated for more efficient utilisation of capacity.

- Congested airports should eliminate price discrimination against large aircraft wherever such discrimination is present. 


\section{Glossary of terms}

A-CDM - Collaborative Decision Making

ACI - Airports Council International, trade association for the world's airport operators, see: www.aci.aero/

ATC - Air Traffic Control

ATMs - Air Transport Movements, the numbers of arrivals and departures at an airport

CAA - Civil Aviation Authority of the United Kingdom, see: www.caa.co.uk/home/

CADM - Co-ordinated Arrival Departure Management

DBS - Distance Based Separation, an air traffic management technique where aircraft arriving at an airport are separated by measures of distance, as opposed to time

DFS - Deutsche Flugsicherung GmbH, the company in charge of air traffic control in Germany, fully owned by the Federal Republic of Germany, see: www.dfs.de/dfs_homepage/en/

DGAC - Direction Générale de l'Aviation Civile - French Civil Aviation Authority, see: www.dgac.fr/

DLR - German Aerospace Centre, national centre for aerospace, energy and transportation research of the Federal Republic of Germany

EUROCONTROL - European Organisation for the Safety and Air Navigation, see: www.eurocontrol.int/articles/who-we-are

FAA - Federal Aviation Administration, see: www.faa.gov/

FACT - Future Airport Capacity Task, reports produced by the FAA analysing the capacity needs of the US Airport System, see: www.faa.gov/airports/planning capacity/media/fact3-airport-capacity-needs-inthe-nas.pdf

IATA - International Air Transport Association, trade association for the world's airlines, see: www.iata.org/Pages/default.aspx

ICAO - International Civil Aviation Organisation, see: www.icao.int/Pages/default.aspx

IMT - Instituto Mexicano del Transporte, see: www.gob.mx/imt

ITF - International Transport Forum at the OECD, see: www.itf-oecd.org/ 
NATS (NATS Holdings) - The main Air Navigation Service Provider in the United Kingdom, see: www.nats.aero/

Night Curfew - A restriction that can be placed on airports banning flights at certain times of the night

Noise Envelope - Limits on several inputs that create aircraft noise i.e. numbers of people affected, or times to create an 'envelope' to limit noise

OECD - Organisation for Economic Co-operation and Development, see: www.oecd.org/

PSO - Public Service Obligation, in the European Union governments use a PSO to procure a scheduled air service on a route that is deemed vital for the economic and social development of the region, but at the same time it is unprofitable for any airline to operate that route under competitive market conditions (known as an Essential Air Service in the USA), see: https://ec.europa.eu/transport/modes/air/internal$\underline{\text { market/pso_en }}$

Schedule delay - The difference between the time that a passenger wants to fly and the airline schedule

SESAR - Single European Sky ATM Research, the European body to define, develop and deploy what is needed to increase Air Traffic Management performance, see: www.sesarju.eu/

Slot - In the IATA Worldwide Slot Guidelines, a permission given by a coordinator for a planned operation to use the full range of airport infrastructure necessary to arrive or depart at a Level 3 airport on a specific date or time, see: www.iata.org/policy/infrastructure/slots/Pages/slot-guidelines.aspx

TBS - Time Based Separation, an air traffic management technique where aircraft arriving at an airport are separated by time intervals rather than distance, see: www.nats.aero/tbs/

TDR - Traffic Distribution Rules, government rules to regulate the distribution of traffic between different airports

Wake Vortex Turbulence - Turbulence which is generated by the passage of an aircraft in flight, see: www.eurocontrol.int/articles/wake-vortex

WSG - Worldwide Slot Guidelines, a set of standards for the management of airport slots produced by IATA member airlines and the community of airport coordinators, see: www.iata.org/policy/infrastructure/slots/Pages/slot-guidelines.aspx 


\section{Introduction}

Major airport investments are essential to meeting the growing passenger and cargo demand, but they are often contentious and controversial. ${ }^{3}$ The risks and uncertainties, particularly in relation to future aviation demand, make the decision-making process difficult. Benefits of airport expansion projects are dispersed and costs, notably noise, are concentrated, which often creates significant opposition to such developments. And even if such developments are agreed, it takes a very long time to build new airport infrastructure. Governments and the aviation sector in general are therefore interested in examining how to improve utilisation of available airport capacity without building new infrastructure.

\section{Scope}

Many governments have ambitious plans for building new airports and expanding existing airport sites, but these developments are often not able to keep pace with rapidly growing aviation demand. Governments and the aviation sector in general are therefore interested in examining how to improve utilisation of available airport capacity without building new infrastructure.

A Roundtable organised by the International Transport Forum at the OECD (ITF) in cooperation with the Instituto Mexicano del Transporte (IMT) brought together transport economists and operational research experts as well as government and industry representatives to identify effective methods of dealing with airport capacity constraints within existing airport infrastructure.

The Roundtable reviewed different factors that have an impact on capacity, including:

- Physical airside and landside constraints

- Airline and airport business models

- Government regulation of airport assets

- Environmental and other policy constraints

The experts then examined the technological and policy levers that can be used to make the use of airport capacity more efficient.

\section{Technological levers:}

- Collaborative Decision Making

- Co-ordinated Arrival Departure Management

- Implementation of time-based separation, rather than distance-based separation

- Better airside and landside coordination through simulation modelling 


\section{Policy levers:}

- Administrative and market-based capacity management

- Eliminating price discrimination against larger aircraft

- Redistribution of traffic in multi-airport systems

\section{Air connectivity and airport capacity considerations}

Policy makers have an interest in making use of existing airport capacity more efficient insofar this would benefit the users of aviation and the wider economy. At the heart of these considerations is the concept of air connectivity (see Box 1). Air connectivity benefits the economy, through facilitating the movement of goods and services, people, ideas, knowledge and investment. It is thus important for policy makers to understand both how to improve air connectivity outcomes and how different government policies and regulations impact air connectivity.

The Roundtable participants were largely in agreement that determining what constitutes an improved connectivity outcome requires both a careful examination of all dimensions of connectivity but also some judgment, possibly by the regulator, as well as consensus agreement of all aviation stakeholders on how to trade different dimensions of connectivity against one another. Increasing throughput of an airport should be considered in the context of its potential impacts on delays, the level of passenger service, as well as all socio-economic impacts relating to air transport (see next section).

When establishing standards with respect to delays and the level of service, the implications on the welfare of passengers need to be taken into account. For example, there may be rationale to accommodate more flights during Christmas time: an increased supply of available seats would likely reduce costs for customers who are often willing to get home and the resulting increased delay would likely be more than offset in terms of passengers' welfare by the reduced cost and less suppressed demand. Similarly, there may be a rationale to accommodate more flights at the busiest times of the day through (if possible) higher values of the declared capacities, as practiced as some Level 3 airports. These can be compensated by a schedule slack at off-peak hours (Jacquillat and Odoni, 2015a). The Roundtable participants concluded that this was an important area for potential future research. 


\section{Box 1. Defining and measuring air connectivity}

In simple terms, air connectivity is about making travel as easy and affordable as possible, given the geographical separation involved. Defining and measuring air connectivity is challenging because it involves scrutinising many different factors that affect it, including terminal and runway capacity, the quality of the management of airport operations, accessibility of the airport to potential passengers, and the affordability of travel.

No airport can provide air connectivity unless airlines decide to use it. ITF (2014b) points out that there are several important factors in the choices airlines make as to which airports to use: potential market size, ease of market access, advantages of spatial concentration, airport visit costs and service levels. As the level of air connectivity provided by an airport is a function of airline operations, the response of airlines to airport investment and pricing strategies and the ways in which they generate profits from air service markets, these factors are crucial considerations in any air connectivity analysis.

Scholars and policy makers have suggested many different methods of measuring air connectivity (see Airports Commission (2013a); Burghouwt and Redondi (2013) for an overview of different metrics). These range from scrutinising a collection of simple metrics, such as number of available direct destinations, frequencies, seat capacity on particular routes or average levels of delay, to more complex connectivity metrics which aim at capturing different dimensions of connectivity in one index.

Putting aside the pros and cons of these two approaches, what is important for the purpose of this paper is that connectivity is not a one-dimensional but a multidimensional concept. This implies that any change to how capacity is utilised needs to be carefully considered through the prism of how it affects all dimensions of connectivity. For example, allowing more air traffic movements (ATMs) at an airport, holding all other factors equal, has two apparent impacts on air connectivity. On the one hand, the number of offered seats and possibly destinations as well as frequencies will increase. On the other hand, more traffic may increase airside and landside congestion, and in turn increase average delays and adversely affect resilience of the airport. Furthermore, these delays are spread around an airport network as delayed aircraft fly onwards creating a spill-over effect.

\section{Air connectivity improvements need to be considered alongside all impacts of air transport, particularly on local communities}

Moreover, any policy change with impact on air connectivity should be considered alongside all positive and negative impacts relating to air transport - on the travellers, the industry, local communities, and the local and national economy. Providing stakeholders with information on such impacts can help increase the level of trust between decision makers, the industry and the local community. The experts noted that a collaborative approach among all stakeholders was crucial to ensuring that those who are negatively impacted by any policy changes to improve air connectivity (particularly in terms of increased noise and air pollution) are adequately compensated.

Such compensation considerations help ensure fairer outcomes and, in consequence, reach consensus among the stakeholders. One of the challenges for government relates to balancing the benefits experienced by a large section of the population, passengers and businesses that support the economic benefits of air travel, against the costs incurred by a relatively small section of the population, those that live near airports. This conflict is clearly visible during policy debates on most prospective airport expansion projects, to which local communities are usually, although not always, strident 
opponents. Local stakeholders can wield significant political power, as seen by the difficulties in airport expansion across the world. To take just one example, the airport in Dusseldorf built a second runway in 1993 for EUR 61 million, however, use of the runway was restricted to the capacity of one runway, due to the so-called "Angerlandvergleich" - a contract between a number of municipalities, the North Rhine Westphalia Transport Ministry and the airport company - signed in 1965 (Niemeier, 2013).

\section{Capacity constraints can limit the development of air connectivity}

At first glance, capacity constraints do not seem to be a global issue. At the beginning of 2017 only 178 airports globally will be Worldwide Slot Guidelines (WSG) Level 3 congested airports (explained later in this section) in the summer season of 2018. Although capacity constraints pertain to only $1 \%$ of all commercial airports in the world, it is not surprising that they bite at the most important airports which provide their countries with the vast majority of the available long-haul destinations. According to IATA's WSG Database, 19 out of 31 world's megacities are served by airports where demand already exceeds the available capacity (Figure 1).

\section{Figure 1. WSG Level 3 congested airports at world's megacities}

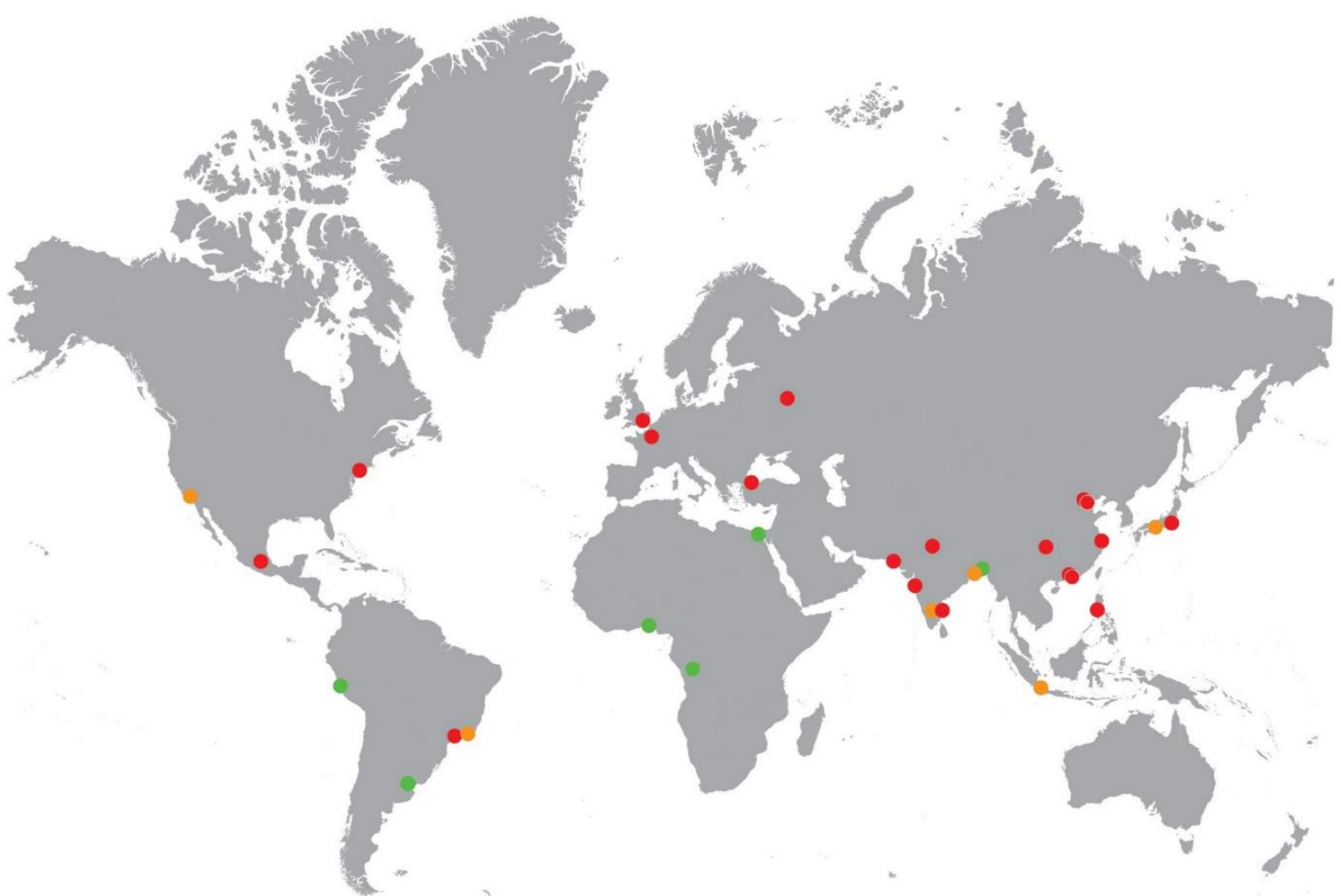

\section{IATA WSG Level 1: adequate capacity of the airport infrastructure to meet demand \\ IATA WSG Level 2: airports with a potential for congestion \\ IATA WSG Level 3: inadequate capacity of the airport infrastructure to meet demand}

Note: A megacity is defined as a metropolitan area with 10 million or more inhabitants (UN, 2016). Source: IATA (2017), Airbus (2016), UN (2016). 
National policies stipulate who determines whether an airport is congested, how the determination is made and, thus, whether or not the slots at a congested airport should be managed. Depending on the country, there are different ways of establishing capacity. In Mexico and Germany, for example, establishing airport capacity is a legislative requirement for certain airports. There are also some "slot controlled" airports in the United States where this is required. In Canada, the capacity of Toronto International Airport is established by the Minister of Transport. For most airports, however, it is the airport itself that declares capacity. This can be achieved through consensus with airline representatives, which is the case, for example, at Amsterdam Schiphol.

The IATA Worldwide Slot Guidelines document (WSG) provides the global air transport community with a single set of standards for the management of airport slots. The document is reviewed on a regular basis to keep up with industry and regulatory changes.

The WSG define three levels of airport congestion:

- Level 1: airports where the capacity of the airport infrastructure is generally adequate to meet the demands of airport users at all times.

- Level 2: airports where there is potential for congestion during some periods of the day, week, or season which can be resolved by schedule adjustments mutually agreed between the airlines and facilitator. A facilitator is appointed to facilitate the planned operations of airlines using or planning to use the airport.

- Level 3: airports where capacity providers have not developed sufficient infrastructure, or where governments have imposed conditions that make it impossible to meet demand. A coordinator is appointed to allocate slots to airlines and other aircraft operators using or planning to use the airport as a means of managing the declared capacity.

In an airport system without capacity constraints or other barriers to entry, competition between airlines would ensure prices that clear the market, maximise welfare rents and minimise excess profits for carriers. The Roundtable participants agreed that any airport that becomes a WSG Level 3 congested airport represents a market failure. When capacity constraints bite, they cause prices to rise and the route network to become suppressed. Capacity constraints can generate scarcity rents, which accrue along the air transport value chain, including to airlines and airports. When the passenger demand to fly from or to a particular airport is greater than the capacity of the airport allows, airlines are able to charge higher prices to passengers.

There have been several studies into the effect of capacity constraints on prices. ${ }^{4}$ For example, SEO Amsterdam Economics and Cranfield University recently estimated that the fare premiums for passengers in Europe due to capacity restrictions at congested European airports to have cost EUR 2.1 billion in the year 2014. They are expected to rise to EUR 6.3 billion per year by 2035 (Burghouwt et al., 2017). It is difficult though to establish which factors precisely account for higher ticket prices, particularly due to lack of data on airport charges vis-à-vis other costs to airlines. There is also a number of different reasons, apart from market power, why higher ticket prices may be expected at major congested hub airports (see Starkie, 2006). Airline representatives often argue that most of the excess economic rents due to congestion do not go to airlines. Moreover, airlines are faced with costs of congestion too, due to resulting delays and resilience issues, and possibly higher airport charges. 
Under the WSG, incumbent airlines enjoy grandfather rights to slots if they meet certain conditions of use i.e. they have the right to use a slot in perpetuity as long as they use it at least $80 \%$ of the time, which is known as the "use-it-or-lose-it rule". The grandfather rights aim to bring stability to the route network and give airlines certainty of operations at a particular site. This is ensured, however, at the expense of fostering competition. In Europe, where grandfather rights are enforced, any substantial acquisition of capacity by new entrants at congested airports is only possible when new capacity becomes available, except where secondary trading is practised: the WSG stipulates that $50 \%$ of available capacity is to be awarded to new entrants unless requests by new entrants are less than $50 \%$.

Capacity constraints can also affect the number of available connections. Faced with a limited number of slots and no room to expand, airlines tend to focus on the most profitable routes. These often are the thickest long haul routes as on these routes airlines can use bigger aircraft and are generally able to extract higher per passenger profit than on short haul routes. While airlines do use capacity in the most efficient way, such dynamics can in turn prevent the development of new links, particularly to destinations which are only emerging in their importance, and affects any potential business opportunities to these markets. Another potential consequence is crowding out of domestic routes. For a hub airport, the loss of marginal routes which feed the hub can make it harder for airlines to grow the route network. At Heathrow, which operates at or near capacity on all days of the year, the total number of domestic airports served on a daily basis dropped from 17 in 1990 to 8 in 2017, hence adversely affecting connectivity between regions of the UK and constraining access from the regions to the national hub.

\section{What can be done to improve air connectivity outcomes?}

There generally are three options to improve air connectivity at a congested airport site:

\section{- Add physical capacity through building new infrastructure}

The Roundtable participants agreed that in most cases airports become WSG Level 3 congested airports due to the lack of effective long-term planning by the policy maker. As scarce capacity makes it difficult for new entrants to enter an airport, capacity constraints create scarcity rents which accrue along the value chain, including to airlines and airports. It is thus important that governments engage in a consultative process of long-term aviation infrastructure planning to bring relevant stakeholders airports, airlines and local communities and businesses - on-board. The experts agreed that it is important for the government to create a policy environment, through appropriate regulation of airports as well as other policies, to foster the delivery of the right kind of infrastructure at the right time.

\section{- Increase throughput of existing capacity}

The Roundtable participants noted that, while increasing throughput of the existing airport capacity is desirable, there is an inherent trade-off between increasing throughput of an airport and delay levels at that airport (and the resulting delays propagating through the system). Any policy intervention to increase throughput at a congested airport, for example through more efficient use of taxiing capacity and faster aircraft turnaround times, needs to be considered in the context of rising delays.

- Manage within constraints of existing capacity

If increasing an airport's physical capacity or its throughput is not an option, the experts concluded that the option of last resort is to consider influencing connectivity outcomes through capacity allocation. This can be done through slot allocation or through slot auctioning, as well as other capacity- 
management mechanisms such as traffic distribution rules, regulatory change, or incentivising traffic reallocation in a multi-airport system within a metropolitan area.

As already mentioned in the introduction, this paper focuses on a suite of methods that can be used to improve air connectivity, and social value that it generates, within existing airport infrastructure.

The Roundtable participants agreed that the aim of improving air connectivity can be effectively accomplished only if the reasons for airport capacity constraints are identified and when the existing capacity is defined and measured through the prism of capacity constraints. Only then the considerations can proceed to defining the toolkit at hand and how effective each of the policy levers may potentially be, and what unintended consequences each of the policies may have. The following sections of the paper tackle these issues in turn.

\section{Defining and measuring airport capacity}

The participants discussed a selection of approaches to define and measure airport capacity. For example, Barnhart et al. (2012) define capacity as the number of movements per hour; Uphamet al. (2003), and Graham and Guyer (1999) - as a function of operational and environmental constraints. More recently academic research on airport operations tends to focus on the relationship between flight schedules, airport capacity and how to mitigate delays (Jacquillat and Odoni, 2015b; Zografos et al., 2017). Mujica et al. (2017) propose defining airport capacity as a function of airline and airport business models, airport infrastructure, regulations, and capacity caps imposed by the government for environmental or society-related reasons.

ACI Europe's position paper on airport capacity (ACI Europe, 2015) defines capacity "as the practical maximum number of operations that a system can serve within a given period of time" (Young and Wells, 2011: 428) and as a combination of:

- Runway capacity,

- Airport geometry,

- Terminal capacity,

- Apron/stand capacity,

- Airspace capacity and

- Surface access capacity.

These capacity drivers determine physical airport capacity.

In the USA, the Future Airport Capacity Task (FACT) takes a long-term outlook for airport capacity of US airports. The third FACT report, FACT 3, was released in January 2015 and uses modelling to determine which airports will be capacity constrained in the future (FAA, 2015). The results are underpinned by the Annual Service Volume (ASV) and National Airspace System (NAS)-wide modelling tools. ASV calculates the yearly demand that results in a given level of average delay in simulated operations. It considers multiple runway configurations at an airport, weighted by the annual frequency of occurrence and utilises an annual estimation of weather conditions for each configuration in 
its calculation. The resulting demand-delay curve can be used to estimate the average annual delay that results at a given level of annual demand.

The NAS-wide simulation uses calculated capacity curves for each airport with adjustments over time for future fleet mixes. This includes runways, airspace, taxiways and gate constraints. This simulates 16 demand days with a mix of weather conditions for several scenarios to estimate future levels of congestion.

In FACT 3, an airport is designated as capacity constrained or congested when the ASV modelling estimates a delay of 7 minutes or more per flight, and the NAS-wide simulation estimates 30 per cent or more of the arrival or departure hours at the airport being congested.

Capacity constraints at airports can be broadly divided into two groups: physical constraints and policy constraints (Table 1).

Table 1 . Factors that define the capacity of an airport

\begin{tabular}{|l|l|}
\hline Constraints & \multicolumn{1}{|c|}{ Description } \\
\hline $\begin{array}{l}\text { Physical constraints } \\
\text { Tanways }\end{array}$ & $\begin{array}{l}\text { The length, number and configuration of runways affects the number of ATMs } \\
\text { The layout and number of taxiways to allow aircraft to enter and leave the runway } \\
\text { affects the number of ATMs } \\
\text { The size and layout of the terminal affects the maximum number of passengers that can } \\
\text { be processed per hour } \\
\text { Tufficient and well laid out apron space enables a maximum number of ATMs to be } \\
\text { loaded and unloaded with passengers and cargo per hour } \\
\text { Efficiency of airspace usage to enable aircraft to land and take off affects the maximum } \\
\text { number of ATMs } \\
\text { Co-ordination of the aircraft at the airport affects a maximum number of ATMs }\end{array}$ \\
Airspace & $\begin{array}{l}\text { Limits on several inputs that create aircraft noise, e.g. numbers of departures, or times } \\
\text { to create an 'envelope' to limit noise } \\
\text { A restriction sometimes placed on airports banning flights at certain times of the night } \\
\text { The level of restrictions placed on passengers and goods at the border, combined with } \\
\text { the processing capability provided, affects the maximum number of passengers and } \\
\text { amount of goods that can be processed per hour } \\
\text { The level of security implemented, combined with the processing capability provided, } \\
\text { affects the maximum number of passengers and amount of goods that can be processed } \\
\text { per hour }\end{array}$ \\
\hline $\begin{array}{l}\text { Policy constraints } \\
\text { Noise envelopes }\end{array}$ Bight curfews & \multicolumn{2}{|c|}{ Border controls }
\end{tabular}

- Physical capacity constraints

How many aircraft and passengers can be served by an airport is limited by the airport's physical infrastructure, i.e. the number and configuration of its runways, aprons, taxiways as well as any limitations of the airspace.

- Policy constraints

Very often the declared capacity of an airport is lower than what physical capacity constraints would otherwise suggest, due to policy constraints put in place. These include noise envelopes, night curfews, 
air quality limits, border controls and security requirements, which are usually implemented to diminish the adverse impacts of aviation activity, notably noise and increasing emissions, on local communities. Box 2 below sets out the limiting factors at the biggest airports in the Netherlands and Mexico Schiphol International and Mexico City International Airport. ${ }^{5}$

\section{Box 2. Declared capacity at Amsterdam Airport Schiphol and Mexico City Airport}

Amsterdam Schiphol currently has a declared capacity of 510000 ATMs. The capacity limit is not set by Schiphol's capacity constraints, but by a set of the following noise restrictions imposed upon the airport:

- Restricted air space usage (minimum flight levels, strict standard arrival and departure routes);

- Limited runway system availability and runway usage at various times of the day (day, evening, night), notably higher tariffs for night flights and noisy aircraft types;

- Regulations on noise-preferential runway usage and ground noise pollution;

- Regulations to minimise the number of noise compromised houses and significantly affected individuals.

The annual cap of 510000 ATMs imposed on the airport is a result of a compromise reached by the government, business and local stakeholders through the Alders Table, a consultative body tasked with the formulation of policy recommendations for the development of Schiphol until 2020. In 2008 the Alders Table advised the Dutch government on how to reconcile the growth of Schiphol Airport with disturbance limitations and the quality of the living environment.

In contrast, at Mexico City Airport the hourly declared capacity of 61 ATMs is determined by physical, and not policy, constraints. The separation between the runways at approximately $300 \mathrm{~m}$ does not allow for independent operations. The capacity of the airport is thus constrained by the two runways having to be operated in a segregated mode, and by the minimum distance between aircraft on a runway requirement. 


\section{What can be done to make more efficient use of existing airport capacity?}

The Roundtable participants agreed on several best practices that can foster more efficient use of existing airport capacity, hence improving welfare of the users of aviation.

There was widespread agreement that airports, airlines, air navigation service providers, and regulators should pursue all possible technical innovations to improve utilisation of available airport capacity. Such tools, however, are very unlikely to deal with the full challenge of capacity constraints at congested airports in the long term. The only credible solution to alleviating capacity constraints is through long-term planning and investment in new infrastructure.

At the same time, technological improvements can reduce the need for policy restrictions constraining capacity in order to reduce adverse impacts of aviation activity, predominantly in terms of noise and air pollution. Such policy considerations could serve as an incentive for the industry to further reduce aircraft noise.

This section of the paper reviews the following tools that can be used to make the use of airport capacity more efficient.

- Technological levers:

- Collaborative Decision Making (A-CDM)

- Co-ordinated Arrival Departure Management (CADM)

- Implementation of time-based separation (TBS), rather than distance-based separation (DBS)

- Better airside coordination through simulation modelling

- Policy levers:

- Administrative and market-based capacity management

- Eliminating price discrimination against larger aircraft

- Redistribution of traffic in multi-airport systems

As for using policy levers to allocation capacity, the experts agreed that governments should act cautiously and avoid intervening in airport capacity allocation unless there are strong reasons for it.

\section{Relaxation of policy constraints on airport capacity due to technological improvements}

The participants noted that some of the capacity shortage is due to capacity restricting policies. Such policies include annual or daily quotas on flights and are generally designed to alleviate some of the adverse impacts of airports on local communities, particularly in terms of noise and air pollution. $\mathrm{CO}_{2}$ emissions are also an increasingly important consideration. As such, policy restrictions on capacity serve an important purpose of mitigating adverse impacts of aviation.

Thanks to technological advancements, which enable production of quieter, more environmentally friendly aircraft, there may be room for relaxing policy constraints on airport capacity. Such an approach could serve as an incentive for the industry to further reduce aircraft noise. 
For example, the development of quieter aircraft can lead to a review of a noise envelope or a night curfew. The experts agreed that constant technological developments in this regard make it important for governments to continue to review caps and limitations imposed on capacity due to the adverse impacts of noise on populations. On the other hand, communities often expect noise performance to improve with time (Sustainable Aviation, 2013) and as such noise reduction does not create as much space for expansion as hoped for by the aviation industry. But that does not exclude a revision of policy constraints put on airports. Amsterdam Schiphol is a case in point: the airport agreed with the communities and other stakeholders that any noise reduction thanks to quieter aircraft operations will result in an increase in the airport's capacity, but only up to the point at which additional aircraft will generate up to $50 \%$ of the noise that was abated due to better aircraft technology.

There are question marks, however, over how effective the policy reviews of caps imposed on airport operations may be in practice. The experts noted that the historic trend of aircraft noise reductions has been slowing down with time, mostly as aircraft manufacturers have been basing their products on the same frame for over past 40 years (Figure 2).

Figure 2. Development of aircraft noise emissions

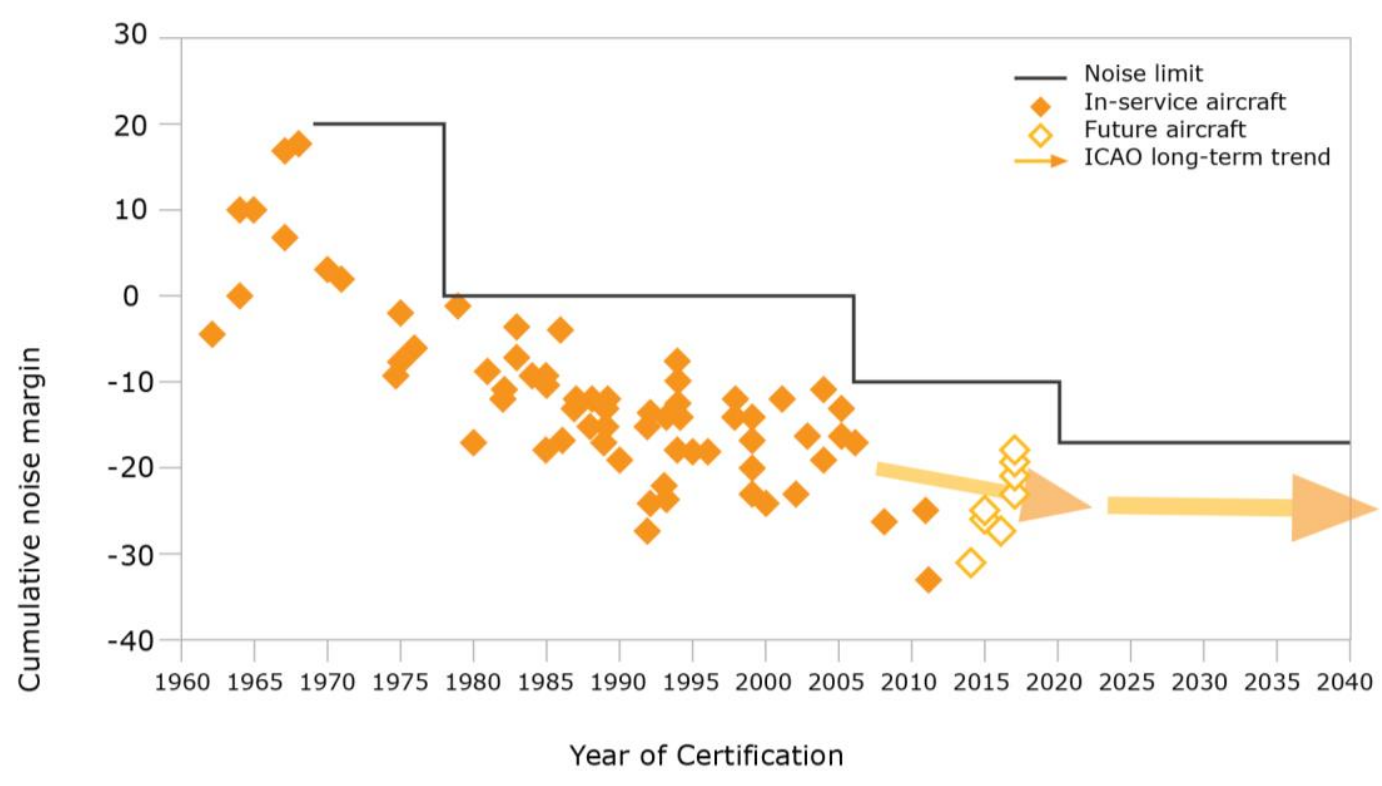

Source: Airports Commission (2013b)

\section{Technology to improve efficiency of airports}

The Roundtable participants discussed different technological advancements that can help increase the existing physical capacity of airports, including:

- Collaborative Decision Making (A-CDM)

- Co-ordinated Arrival Departure Management (CADM)

- Implementation of time-based separation (TBS) rather than distance-based separation (DBS)

- Better airside and landside coordination through simulation modelling 


\section{Collaborative Decision Making (A-CDM)}

A-CDM ${ }^{6}$ is a tool which provides accurate and timely information on the pre-departure sequence consisting of stand, push back, taxi, holding, queuing and take-off (Figure 3). A-CDM uses a live ground radar feed of aircraft positions to give a pinsharp picture of airport operations. This picture is distributed to all relevant parts of the airport: air traffic management, ground handlers, gate operators and aircraft operators. Collaboration between these parties leads to reduced congestion on the aprons and taxiways, better gate utilisation, reduced fuel burn, optimal use of ground handling resources and reduced waiting times for passengers. NATS state that the A-CDM implementation at Heathrow has increased capacity by one aircraft movement every two hours and A-CDM is fully implemented at 22 different airports across Europe. ${ }^{7}$

Figure 3. The pre-departure sequencing process

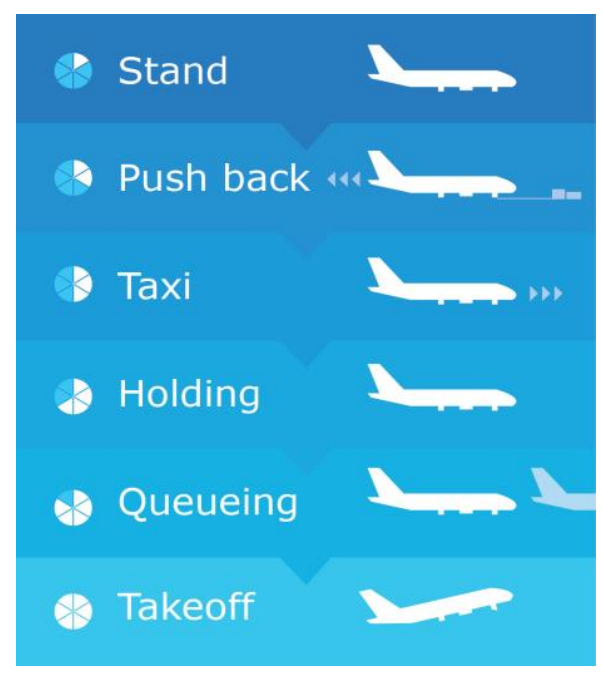

Source: NATS

\section{Co-ordinated Arrival Departure Management (CADM)}

Another tool to more efficiently manage arrivals at mixed mode runways is Co-ordinated Arrival Departure Management (CADM). Air Traffic Control decides on the sequencing of aircraft arriving at an airport based on safety and efficiency reasons. However, the spacing between arrivals is not always optimal for smooth transitions between departures and arrivals. The CADM system creates an appropriate, automatic tailoring of arrival gaps, taking into account the departure traffic, i.e. queuing aircraft on the ground. This can improve throughput and reduce delays. Simulation runs of two and a half hours at Frankfurt Airport by the German Aerospace Centre (DLR) (Böhme et al., 2007) showed an average increase in departures per hour and maximum overall throughput per hour when CADM was used (Table 2).

Table 2. CADM can provide significant improvements to efficient airport infrastructure use (throughput per hour depending on whether CADM used)

\begin{tabular}{|c|c|c|c|}
\hline & Mean departures per hour & Mean arrivals per hour & $\begin{array}{c}\text { Maximum overall } \\
\text { throughput per hour }\end{array}$ \\
\hline Coordinated & 21.41 & 31.25 & 54 \\
\hline Uncoordinated & 18.97 & 31.43 & 52 \\
\hline
\end{tabular}

Source: Böhme et al. (2007) 


\section{Time based separation}

Traditionally aircraft arrivals had been separated by distance required between aircraft. Time Based Separation (TBS), however, enables separation of aircraft by time instead. This is particularly effective at mitigating the negative effects on the landing rate of headwinds at an airport. Headwinds can cause delays when runways are operating at full, or close to full utilisation. This is because, compared to operations in still conditions, the groundspeed of the aircraft is reduced by the headwind. Since in a DBS the distance between aircraft needs to remain fixed, the time between aircraft landing on a runway becomes longer, reducing throughput and causing delays at peak times. Time Based Separation allows the distance between aircraft to be adjusted for the headwinds so that the aircraft landing rate is not reduced.

Air traffic management is an area where much progress has been made in the past and the experts agreed that it could still provide efficiency gains in the future. Increasing efficiency of air traffic management is at the heart of SESAR ${ }^{8}$ - the European body to define, develop and deploy what is needed to increase ATM performance - or its US equivalent, NextGen ${ }^{9}$.

As part of the Single European Sky ATM Research (SESAR) project to improve Air Traffic Management, NATS have been operating Time Based Separation (TBS) since March 2015 at Heathrow, where in 2014, wind was accountable for $44 \%$ of all delays. The implementation of TBS led to an average 62\% reduction in wind-related Air Traffic Flow Management delays and allowed for 2.6 additional ATMs per hour to be operated in strong winds (NATS, 2015).

TBS is mandated to be in operation at Europe's busiest airports by 2024. A key feature of TBS is that it uses downlinked real time live wind data from the aircraft to dynamically calculate the headwind effect on final approach and determine the optimal safe wake vortex spacing between aircraft. Separation indicators are provided to controllers to assist with managing final approach separations. Before implementing TBS at Heathrow, NATS and EUROCONTROL conducted real time simulations to develop algorithms, assess controller workload and validate benefits. They also studied the arrival paths of over 150000 aircraft at London Heathrow, using state of the art equipment to accurately measure the behaviour of aircraft wake vortices. This helped to inform the safety case for the introduction of TBS.

Aircraft are separated by distance when coming in to land to ensure they do not suffer turbulent effects caused by wake vortices from the aircraft in front. Wake vortices are turbulence that forms behind an aircraft when it passes through the air, particularly at the wing tips which make up most of the effect. The distance between two aircraft is normally determined by their respective sizes and weight. Size and weight determine into which one of six main wake vortex categories an aircraft belongs. The required distance between aircraft at landing is then determined through that classification. Separating aircraft by time instead of distance offers the potential to reduce these separations and therefore increase the number of aircraft able to land on a runway.

In the European Union, the European Wake Vortex Re-categorisation (RECAT-EU) will soon replace the six categories mentioned above with a new, more optimised categorisation to more accurately reflect the size of the vortex created and effect it causes. This re-categorisation will enable the separation distance between aircraft to be reduced and thus improve the landing rate.

In the years to come, 'pairwise separation' will replace the categorisation of aircraft in RECAT- EU and create specific categories for over 96 aircraft types, refining further separation distances. 'Optimised Runway Delivery' technology will also be adopted to enable traffic controllers to achieve more efficient separation between aircraft. 
At Heathrow these improvements are expected to increase the landing rate from 40-45 aircraft per hour with light headwinds and 32-38 per hour in strong headwinds to $42-47$ per hour in light headwinds and $38-42$ in strong headwinds. ${ }^{10}$

In the USA, NextGen, the FAAs equivalent of SESAR, is utilising similar technologies for airspace. Herrera et al. (2017) discuss wake vortices and technologies that can be used to increase airport capacity such as the Aircraft Wake Safety Management tool.

\section{Better airside coordination through application of simulation modelling}

Simulation models ${ }^{11}$ are tools used by transport infrastructure operators and in other fields to analyse how efficiently people and vehicles flow through a certain space. They use a detailed set of inputs to explain how the existing infrastructure is set up, and a detailed set of assumptions about how actors in that system behave. By changing the airport layout and other variables, it is possible to explore how existing infrastructure can be more effectively utilised. Simulation models can be used to simulate how passengers move through terminals, how aircraft move through taxiways and how take offs and landings are sequenced at single and multi-runway airports. Optimisation methods have also the potential to improve allocation of slots through providing decision makers with information on trade-offs between increasing capacity and slot allocation efficiency (Zografos et al., 2017). As models are becoming more detailed and accurate, they are becoming more useful. The experts agreed that airports should continue to use the latest modelling tools to ensure airport infrastructure usage was optimised.

\section{Policy mechanisms to make more efficient use of existing airport capacity}

The Roundtable participants discussed policy mechanisms that can be used to make more efficient use of existing airport capacity. ${ }^{12}$

\section{Administrative and market-based capacity management}

A slot is generally defined as an authorisation to land or depart an aircraft at a specific time at a specific airport. One slot is required for a landing and another (at a different time) is required for a takeoff. Sometimes the term slot is used to represent a pair of slots, both for landing and departing. There are a number of subtleties in defining slots. For example, the actual flight operation might be at a different (usually later) time than authorised due to adverse weather conditions, need for maintenance or flight loading delays.

At the heart of slot allocation lies the issue of distributing access to scarce airport capacity at peak hours of demand. The constraints may arise due to insufficient physical capacity of the airport (e.g. runway or terminal) or processing capacity of aircraft - e.g. through airspace restrictions - or passengers, e.g. at the passport control.

There is some ambiguity as to whether the right to operate a slot constitutes its ownership. As slot sales at several airports have revealed, there is a monetary value to the entitlement at slot restricted airports. US airlines have pledged slot entitlements as collateral to financial institutions. For example, as part of their 2014 credit and guarantee agreement with Citibank, American Airlines and AAG pledged slot entitlements as collateral. ${ }^{13}$

In general, constrained airport capacity can be allocated in three different ways:

- No capacity management mechanism 
- Administrative capacity management measures (administrative slot allocation, traffic distribution rules)

- Market-based capacity management measures (slot auctioning, secondary slot trading, peak pricing)

Airport capacity can be managed through a combination of these approaches. For example, at congested airports in the UK primary administrative slot allocation is coupled with secondary slot trading.

The participants noted that none of the allocation approaches can ultimately deal with the problem of excess demand for airport capacity, rather their aim is to allocate scarce capacity in the most efficient possible way. The current policy making in the area of slot allocation mostly focuses on ensuring that the mechanisms to allocate slots at capacity constrained sites maximise economic efficiency i.e. slots are allocated to those airlines that can use them to the greatest benefit to the users of aviation (passengers and air freight forwarders). This in practice means balancing a system in which the benefits of slot concentration ${ }^{14}$ and the benefits of competition are maximised.

\section{No capacity management mechanism}

At US airports, except for three high profile exceptions (JFK International Airport and LaGuardia Airport in New York, and Ronald Reagan National Airport in the Washington, D.C. area), carriers can generally schedule flights as they wish, in coordination with airport operators. ${ }^{15}$ The most obvious advantage of having no particular allocation mechanism at a congested airport is its administrative simplicity, while the disadvantage is the potential for delays created by over-subscription of airlines to airport slots during the busiest periods during the day. ${ }^{16}$ In 2007, the nation-wide impact of air travel delays in the United States was estimated at over USD 30 billion, borne by the airlines, passengers, and society at large (Ball et al., 2010).

As Starkie (2006) points out, however, the marginal costs of delays at airports dominated by one carrier or an alliance are often overstated. This is because the delay costs that an airline imposes (by choice, as there is no slot allocation mechanism in this case) on its own operations when it adds an additional flight to the peak are internalised by that airline. The process of internalisation takes into account the impact of adding the additional flight on the operating costs of all other flights the airline operates at the airport. These costs are internalised into the airline's business equation so they do not constitute a negative externality to that airline (although they do to passengers and other carriers). ${ }^{17}$ Hence, the more slots are concentrated in the hands of one carrier or alliance, the smaller the externality. In an extreme case of a monopoly airline serving the airport there will be no delay externalities, even when the airport appears to be congested, and the economically efficient outcome is reached without application of any market-based or other slot allocation mechanisms. This may apply to many congested hub airports in Europe and in the Middle East which are dominated by one hub carrier (Airports Commission, 2013a). 


\section{Administrative capacity management measures (administrative slot allocation, traffic distribution rules)}

\section{Administrative slot allocation}

Administrative slot allocation at congested airports is by far the most commonly used method of distributing scarce airport capacity. Under an administrative slot allocation, slots are allocated by a coordinator using a prescribed set of allocation criteria.

The International Air Transportation Association (IATA), in conjunction with the community of airport coordinators, publishes the Worldwide Slot Guidelines (WSG) which provides guidance on which rules should govern the allocation of slots to airlines. The WSG recommends slot allocation to be introduced at Level 3 congested airports and include a number of key principles when allocating slots. WSG are not a legally binding instrument and countries can follow their own local rules for allocating slots, or complement the WSG with specific additional rules. In the European Union, for example, Council Regulation (EEC) No 95/93 of 18 January 1993 created legally binding rules on slot allocation closely aligned with the WSG (and which have been subsequently updated).

The participants agreed that applying a slot allocation mechanism based on the IATA WSG can reduce congestion and, if appropriately designed, achieve significant welfare benefits for aviation users. The WSG provides a mechanism to seek balance between the benefits of competition and the benefits of slot concentration, which largely reflects the current industry consensus on the matter.

IATA (2017) is currently working with ACI and the Worldwide Airport Coordinators Group on a Strategic Review of the WSG, to fully take into consideration the interest of airport operators and passengers. Participants expect the Strategic Review to improve the WSG through the active participation of states, airlines, airport operators, and slot coordinators.

The WSG has evolved as the industry liberalised. A particularly important policy change was the adoption of allocating $50 \%$ of available slots to new entrants to enhance competition. Further evolution can be expected in the future to address policy concerns related to efficient outcomes. At the $39^{\text {th }}$ ICAO Assembly in 2016, ACI, the Worldwide Airport Coordinators Group and IATA committed to collaborate on a Strategic Review of the WSG and report to states in 2019 at the 40th assembly.

However, administrative slot allocation is economically inefficient, as it does not reflect the scarce nature of airport slots and does not include a specific mechanism to ensure that slots are allocated to those who attach the highest value to them, or can deliver the highest benefits to the consumers (see, for example, DotEcon, 2006).

Moreover, the principle of slot 'grandfathering' - a rule which gives the right to existing slot users to hold onto the slots they use provided they utilise their slots for at least $80 \%$ of the time - can effectively constrain new entrants from operating from congested sites unless new capacity becomes available. All participants agreed that these barriers to entry can be at least partially alleviated through pairing WSG with secondary slot trading.

\section{Traffic Distribution Rules (TDRs)}

Traffic redistribution through imposition of Traffic Distribution Rules (TDRs) was also discussed. The participants concluded that banning specific types of aviation (general or military) from civil aviation airports can have positive impacts on air connectivity. As an example, Heathrow banned general 
aviation flights completely and freight-only flights at peak periods. In Paris, Le Bourget airport serves general aviation and business jets, freeing up some capacity at Charles de Gaulle and Orly for additional scheduled passenger services.

The experts also concluded that any attempt to segregate traffic usually leads to poor efficiency and air connectivity outcomes, as demonstrated recently by TDRs imposed on the Milan airport system (see, for example, Humphreys, 2003) or the more dated decision to move flights to/from Canada and Spain to Gatwick from Heathrow, which had to be promptly reversed.

If TDRs are to be introduced, the experts agreed that they would have to be easy to understand and non-discriminatory, with interventions targeted and proportionate, implemented in a transparent way with independent and impartial overseers.

\section{Market-based measures (slot auctioning, secondary slot trading, peak pricing)}

\section{Slot auctioning}

Slot auctioning, as a market-based allocation mechanism, enables the scarce airport capacity to be allocated to the carrier who values it most (or has the highest "willingness to pay"). If the auctioning is appropriately designed and administered, it may allocate slots in a way that may enhance efficiency and encourage competition between carriers.

Auctions come in many different formats, e.g. the "English auction" in which bidders successively offer higher prices until one bidder who offers the highest price remains, or the "Dutch auction" in which the auctioneer starts the auction with a high price and gradually lowers it until one bidder is willing to pay. The literature suggests a number of other ways in which slots could be auctioned to airlines.

For example, Plott et al. (1989) suggests a 'sealed-bid, one price auction' in which sealed bids indicating the highest price that the bidder is willing to pay are submitted and then arranged from the highest to the lowest. The highest bids are then accepted (if five slots are auctioned, then the five highest bids are accepted), but the winning bidders pay the price of the lowest accepted bid. If the bids reflect carriers' maximum willingness to pay, which is derived from the expected revenue for prospective flights, then significant efficiency gains can be achieved.

Pricing slots is strongly opposed by airlines who perceive such an approach as another way for the airport or the ministry in charge (or whoever sells the slots) to erode airline profit margins.

Some participants remarked that auctioning slots could potentially solve the challenge of funding new airport capacity. Government could sell slots and use the funds to develop new infrastructure or compensate local communities for the adverse environmental impacts of aviation (such as noise or pollution). For such a mechanism to be effective it would have to be subject to regulatory oversight to contain any tendency for gold-plating airport facilities. Where expansion is not feasible, revenues from slot auctions should be regarded as a public resource, accruing to the public exchequer rather than the airport. In the literature, an argument that airports could finance new infrastructure through slot sales is pitched against the argument that the airport may be incentivised to ensure that the infrastructural development lags behind demand in order to maximise the rents collected from selling scarce airport capacity (see, for example, Sentance, 2003).

The participants discussed whether the implementation of slot auctioning in place of an administrative slot allocation was possible in practice. The discussion stressed that it would be difficult 
to persuade the incumbent airlines to support such a move. One proposed solution would be an introduction of a periodic withdrawal of all or a proportion of slots from incumbents and auctioning those slots to the highest bidder (see, for example, Humphreys, 2003). This, however, bears the risk of an extreme disruption in the airline markets, especially for airline route scheduling and for airports that rely on long-term airline partners for their businesses. The withdrawal of slots from incumbents could be particularly problematic wherever airlines have made significant investments in the airport infrastructure, such as in many airports in the USA. It was also argued that slot auctioning could significantly affect the enterprise value of airlines. Slots have been used as collateral for debts and placed on balance sheets of airlines. Withdrawing and auctioning slots could significantly affect airlines' business values.

A partial slot auctioning is in fact a mechanism in theory imposed on the airport in Mexico City. The 2010 Law on Airports contains provisions (95-100) relating to the allocation of airport slots. This included that auctioning, rather than rationing, is used to distribute slots a) whenever slots become available due to non-use or under-use and b) if the airport is congested for three consecutive years the law states that the airport manager should remove $10 \%$ of slots from each carrier (with the carriers able to determine which slots should be removed) and auction these slots. This, however, is yet to happen (OECD, 2017).

Some participants noted that the transfer of rents to airports might be problematic, particularly if the airport operator could put slot auction revenues into the non-aeronautical till. This problem could be solved by putting the revenues from slot auctioning into the aeronautical revenue till to offset landing fees. Some participants also argued that slot auctioning may result in incumbent airlines obtaining the slots anyway due to their higher slot purchasing powers and possibly the lack of genuine competitors. For example, at the end of 2015 slots were auctioned at the Guangzhou Baiyun International Airport in China. ${ }^{18}$ Most of the slots were bought by the nation's four largest airlines and their affiliates for CNY 550 million (EUR 78 million).

\section{Secondary slot trading}

Secondary trading allows airlines to trade slots which have been previously allocated to them. Trading allocates slots to airlines who value them more highly than the previous users, hence increasing economic efficiency in the system. ${ }^{19}$ While the European Commission released a Communication in 2008 which noted the advantages of secondary trading of slots, it is still a relatively uncommon practice in the EU, except for the UK. This is despite the Commission's assurances that it would not seek infringement proceedings against "Member States where such exchanges take place in a transparent manner, respecting all the other administrative requirements for the allocation of slots set out in the applicable legislation." 20

In many countries secondary trading may be happening "under the table" but the extent of this is unknown. An alternative version of secondary slot trading is when one airline buys another airline in order to use its slots. For example, British Airways purchased bmi in 2012, hence receiving 56 valuable slot pairs at Heathrow Airport (although it was forced to give up 14 of these pairs by the European Commission) (European Commission, 2012).

Some participants argued that administrative allocation of slots coupled with secondary trading of slots would deliver the greatest economic benefits of all the options discussed. However, there is also a risk that dominant players in the market can use secondary trading to increase their market share. According to the Centre for Aviation (CAPA, 2013), in the summer of 2001, British Airways held 36\% of the slots at Heathrow, by summer 2012 its share of slots had grown to $44.1 \%$, largely as a result of secondary slot trading. A report by Steer Davies Gleave (2011), commissioned by the European 
Commission, noted though that secondary trading at Heathrow increases allocative efficiency at the airport, without an overall negative impact on competition.

\section{Peak pricing}

Charging a premium for those times of the day when demand is highest is another possible way to alleviate delays at congested airports. This can be achieved through imposing higher landing, passenger and/or aircraft parking-related charges during peak hours.

The price differential is intended to redistribute the demand for airport facilities towards off peak periods and reduce congestion (Jones et al., 2004). While discussion of peak pricing has been put forward by Levine as long ago as 1969, it has rarely been put into practice. The advantage of peak pricing is that the capacity will be allocated to the airlines which value it the most. Additional costs will likely be passed onto the user and thus consumers who value travelling at peak times will pay more for it (Czerny et al. 2008).

Implementing peak pricing, however, can have a detrimental effect on connectivity. Incentivising flights to spread across the day may dampen hub connectivity (and the benefits to the route network that go with it - see Burghouwt, 2013). There is also a question of how effective peak pricing may be. ICAO (2013), for example, argues that the differentials between peak and off-peak pricing have to be very large for airlines to accept the operational inconvenience of using the airport at off-peak times. Such a conclusion is supported by practical evidence from the use of peak pricing at major airports, such as Heathrow.

\section{Eliminating price discrimination against larger aircraft}

Some experts noted that incentivising the use of larger aircraft by airlines can potentially reduce capacity pressures at more congested airports. In fact, the trend toward the use of larger aircraft is already being observed at congested airports. For example, in 2016 one in every ten passengers at London Heathrow airport flew in an A380 (Airbus, 2017), an increase from 6\% in 2014. The trend is also reflected in aircraft orders for narrow body aircraft. For instance, for the Airbus A320 family, in 2010 $13 \%$ of orders were for the bigger A321s, 74\% for A320s and 13\% for the smallest A319s. By 2015 this had changed to $38 \%$ of orders for A321s, 57\% for A320s and only 5\% for A319s (Airbus, 2016).

The experts were clear that using larger aircraft should be an important part of the policy mix for increasing capacity, with airports having an important role to play in combating any discrimination against larger aircraft in their charging policies. In particular, weight-based landing fees at some congested airports imply higher charges for bigger aircraft. This fee structure originates in revenue generation price discrimination, and originally adopted for airport and air traffic control charging by ICAO in the early post Second World War years appropriate for smaller and uncongested airports and should be reviewed at capacity constrained airports.

\section{Redistribution of traffic in multi-airport systems}

Experts also discussed how governments can increase efficiencies of multi-airport systems through redistributing traffic across airports in the same city region. In Amsterdam, for example, there have been moves to encourage traffic to redistribute to other airports in the Netherlands, currently to Eindhoven and in the future also to Lelystad. The focus is on moving airline operations that are not central to the hub function of Schiphol airport. This was compared to efforts in Mexico to encourage more traffic at Toluca airport to relieve the congested Mexico City hub. 
The participants agreed that the most productive way of encouraging such traffic redistribution is through removing access barriers to airports, particularly in relation to surface access. This was a strategy taken up by the UK Airports Commission which recommended to the UK Department for Transport in 2013 how surface access to low-cost airports for London could be improved to alleviate some of the pressures on the most congested airports in the system, Heathrow and Gatwick.

\section{References}

ACI Europe (2015), Position Paper on Airport Capacity, Airports Council International Europe, Brussels, www.aci-europe.org/component/downloads/downloads/4448.html.

Adler, N. and E. Yazhemsky (2017), "To Allocate Slots or Not: That is the question", International Transport Forum Discussion Papers, No. 2017/25, OECD Publishing, Paris, www.itfoecd.org/sites/default/files/docs/allocate-slots-or-not.pdf.

Airbus (2016), “Mapping Demand”, Global Market Forecast 2016/2035, Airbus, Toulouse, www.airbus.com/company/market/global-marketforecast-2016-2035.

Airbus (2017), The A380 double-decker helps relieve congestion at London Heathrow airport, www.airbus.com/newsroom/news/en/2017/01/the-a380-double-decker-helps-relieve-congestionat-london-heathrow-airport.html (accessed 20 July 2017).

Airports Commission (2013a), "Aviation Connectivity and the Economy", Discussion Paper 02, Airports Commission, London, www.gov.uk/government/uploads/system/uploads/attachment data/file/138162/aviationconnectivity-and-the-economy.pdf.

Airports Commission (2013b), “Aviation Noise", Discussion Paper 05, Airports Commission, London www.gov.uk/government/uploads/system/uploads/attachment_data/file/223764/airportscommission-noise.pdf.

Airports Commission (2015), Final Report, Airports Commission, London, www.gov.uk/government/uploads/system/uploads/attachment_data/file/440316/airportscommission-final-report.pdf.

Ball, M. et al. (2010), "Total Delay Impact Study: A Comprehensive Assessment of the Costs and Impacts of Flight Delay in the United States", NEXTOR Final Report, October, www.isr.umd.edu/NEXTOR/pubs/TDI_Report_Final_10_18_10_V3.pdf.

Barnhart, C. et al. (2012), "Demand and capacity management in air transportation", EURO Journal on Transportation and Logistics, Vol. 1, Springer, Berlin, pp. 135-155. 
Böhme, D., R. Brucherseifer and L. Christoffels (German Aerospace Centre (DLR)) (2007), "Coordinated Arrival Departure Management", $7^{\text {th }}$ USA/Europe ATM 2007 R\&D Seminar, Barcelona, www.atmseminar.org/seminarContent/seminar7/papers/p_102_IAC.pdf.

Brueckner, J.K. (2002), "Internalisation of airport congestion", Journal of Air Transport Management, Vol. 8/3, Elsevier, Amsterdam, pp. 141-147.

Brueckner, J.K. (2005), "Internalization of airport congestion: A network analysis", International Journal of Industrial Organization, Vol. 23/7-8, Elsevier, Amsterdam, pp. 599-614.

Burghouwt, G. (2013), “Airport Capacity Expansion Strategies in the era of Airline Multi-hub Networks", International Transport Forum Discussion Papers, No. 2013/05, OECD Publishing, Paris, www.itf-oecd.org/sites/default/files/docs/dp201305.pdf.

Burghouwt, G. (2017), "Influencing Air Connectivity Outcomes”, International Transport Forum Discussion Papers, No. 2017/24, OECD Publishing, Paris, www.itfoecd.org/sites/default/files/docs/influencing-air-connectivity-outcomes.pdf.

Burghouwt, G. and R. Redondi (2013), "Connectivity in Air Transport Networks: An Assessment of Models and Applications", Journal of Transport Economics and Policy, Vol. 47/1, JSTOR, New York, pp. 35-53.

Burghouwt, G. et al. (2017), "The impact of airport capacity constraints on air fares", Final report commissioned by ACI Europe, SEO Amsterdam Economics, January, www.seo.nl/uploads/media/2017-

04_The_impact_of_airport_capacity_constraints_on_air_fares.pdf.

CAPA (2013), Heathrow Airport's slot machine: hitting the jackpot again? https://centreforaviation.com/insights/analysis/heathrow-airports-slot-machine-hitting-the-jackpotagain-108646 (accessed 20 July 2017).

Czerny, A.I. et al. (eds.) (2008), Airport slots: international experiences and options for reform, Ashgate Publishing, Aldershot.

DotEcon (2006), “Alternative allocation mechanisms for slots created by new airport capacity", Report commissioned by the Department for Transport, DotEcon, September, www.dotecon.com/assets/images/slotallocation2006.pdf.

EUROCONTROL (2017), Airport CDM Implementation Manual, The European Organisation for the Safety of Air Navigation, Brussels, www.eurocontrol.int/sites/default/files/publication/files/airport-cdm-manual-2017.PDF (accessed 20 July 2017).

European Commission (2012), Mergers: Commission approves acquisition of British Midlands (bmi) by IAG subject to conditions, http://europa.eu/rapid/press-release IP-12-338 en.htm (accessed 20 July 2017).

EEC (1993), Council Regulation (EEC) No 95/93 of 18 January 1993 on common rules for the allocation of slots at Community airports, Official Journal L 014, European Economic Community, 22/01/1993 P. 0001-0006. 
FAA (2015), FACT3: Airport Capacity Needs in the National Airspace System, Federal Aviation Administration, Washington, D.C., www.faa.gov/airports/planning_capacity/media/FACT3Airport-Capacity-Needs-in-the-NAS.pdf.

Frontier Economics (2014), "Impact of airport expansion options on competition and choice", Report commissioned by Heathrow Airport, Frontier Economics, April, https://your.heathrow.com/takingbritainfurther/wp-content/uploads/2014/04/frontier-reportImpact-of-airport-expansion-options-on-competition-and-choice.pdf (accessed 20 July 2017).

Graham, B. and C. Guyer (1999), "Environmental sustainability, airport capacity and European air transport liberalization: irreconcilable goals?". Journal of Transport Geography, Vol. 7/3, Elsevier, Amsterdam, pp. 165-180.

Herrera García, A. (2017), “Alternative Solutions to Airport Saturation: Simulation models applied to congested airports", International Transport Forum Discussion Papers, No. 2017/23, OECD Publishing, Paris, www.itf-oecd.org/sites/default/files/docs/alternative-solutions-airport-saturationsimulation-models.pdf.

Humphreys, B. (2003), "Slot allocation: a radical solution", in Boyfield, K. (ed.) A Market in Airport Slots, The Institute of Economic Affairs, London, https://iea.org.uk/wpcontent/uploads/2016/07/upldbook256pdf.pdf.

IATA (2017), Worldwide Slot Guidelines, http://www.iata.org/policy/slots/Pages/slot-guidelines.aspx (accessed 20 July 2017).

ICAO (2013), Airport Economics Manual, International Civil Aviation Organisation, Montréal, www.icao.int/sustainability/Documents/Doc9562 en.pdf.

ITF (2014a), Expanding Airport Capacity in Large Urban Areas, OECD Publishing, Paris. http://dx.doi.org/10.1787/9789282107393-en.

ITF (2014b), Expanding Airport Capacity: Competition and Connectivity. The case of Gatwick and Heathrow, International Transport Forum, Paris, www.itfoecd.org/sites/default/files/docs/expanding-airport-capacity-competition-connectivity-gatwickheathrow.pdf.

Jacquillat, A. and A.R. Odoni (2015a), "An Integrated Scheduling and Operations Approach to Airport Congestion Mitigation", Operations Research, Vol. 63/6, The Institute for Operations Research and the Management Sciences, Catonsville, pp. 1390-1410.

Jacquillat, A. and A.R. Odoni (2015b), "Endogenous control of service rates in stochastic and dynamic queuing models of airport congestion", Transportation Research Part E: Logistics and Transportation Review, Vol. 73, Elsevier, Amsterdam, pp. 133-151.

Jones, I. et al. (2004), "Study To Assess The Effects Of Different Slot Allocation Schemes", Report commissioned by the European Commission's DG TREN, NERA Economic Consulting, January, https://ec.europa.eu/transport/sites/transport/files/modes/air/studies/doc/airports/2004_01_slot_allo cation_schemes.pdf.

Levine, M.E. (1969), "Landing Fees and the Airport Congestion Problem", Journal of Law and Economics, Vol. 12/1, University of Chicago Press, Chicago, pp. 79-108. 
Mayer, C. and T. Sinai (2003), "Network Effects, Congestion Externalities, and Air Traffic Delays: Or Why Not All Delays Are Evil”, The American Economic Review, Vol. 93/4, JSTOR, New York, pp. 1194-1215.

Mott MacDonald (2006) , "Study on the Impact of the Introduction of Secondary Trading at Community Airports", Report commissioned by the European Commission, Mott MacDonald, November, www.euaca.org/up/files/DocsEUROPE/EU REGULATION 9593 AS AMENDED Slot Regul ation/2006 slots final report.pdf 211108 054651.pdf (accessed 20 July 2017)

Mujica Mota, M., G. Boosten and C. Zuniga (2017), "Time to Sweat the Assets? The analysis of two airport cases of restricted capacity in different continents", International Transport Forum Discussion Papers, No. 2017/26, OECD Publishing, Paris, www.itfoecd.org/sites/default/files/docs/airport-restricted-capacity-analysis.pdf.

NATS (2015), Beyond Expectations: Intelligent Approach to delivering airport resilience, www.nats.aero/discover/intelligent-approach/ (accessed 20 July 2017).

NATS (2017), Collaborative decision making, National Air Traffic Services, http://www.nats.aero/discover/collaborative-decision-making (accessed 20 July 2017).

NATS and SESAR (2017), Enhanced Time Based Separation (eTBS), National Air Traffic Services, Whiteley and Single European Sky ATM Research, Brussels, www.nats.aero/wpcontent/uploads/2017/03/Full_eTBS_PresentationV1.pdf.

Niemeier, H.-M. (2013), "Expanding Airport Capacity under Constraints in Large Urban Areas: The German Experience", International Transport Forum Discussion Papers, No. 2013/04, OECD Publishing, Paris, http://dx.doi.org/10.1787/5k46n45fgtvc-en.

OECD (2017), Review of the Regulation of Freight Transport in Mexico, OECD Publishing, Paris. http://dx.doi.org/10.1787/9789264268364-en.

Plott, C.R., D.M. Grether and R.M. Isaac (1989), The Allocation of Scarce Resources: Experimental Economics and the Problem of Allocating Airport Slots, Westview Press, Boulder.

PwC (2013), "Fare differentials: Analysis for the Airports Commission on the impact on the capacity constraints on air fares", Final report commissioned by the Airports Commission, PricewaterhouseCoopers, London, December, www.gov.uk/government/uploads/system/uploads/attachment_data/file/372332/economicanalysisconsultants-reports.zip.

Sentance, A. (2003), “Airport slot auctions: desirable or feasible?”, Utilities Policy, Vol. 11/1, Elsevier, Amsterdam, pp. 53-57.

Starkie, D. (2006), “The Dilemma of Slot Concentration at Network Hubs", in Czerny et al. (eds.) How to make slot markets work, Ashgate, Aldershot.

Steer Davies Gleave (2011), "Impact assessment of revisions to Regulation 95/93", Final report commissioned by the European Commission's DG MOVE, Steer Davies Gleave, March, https://ec.europa.eu/transport/sites/transport/files/modes/air/studies/doc/airports/2011-03-impactassessment-revisions-regulation-95-93.pdf. 
Jagoda Egeland and Paul Smale - Capacity building through Efficient Use of Existing Airport Infrastructure

Sustainable Aviation (2013), The SA Noise Road-Map: A Blueprint for Managing Noise from Aviation Sources to 2050, Sustainable Aviation, www.sustainableaviation.co.uk/wpcontent/uploads/2015/09/SA-Noise-Road-Map-Report.pdf.

Upham, P. et al. (2003), "Environmental capacity and airport operations: current issues and future prospects", Journal of Air Transport Management, Vol. 9/3, Elsevier, Amsterdam, pp. 145-151.

UN (2016), The World's Cities in 2016, United Nations, www.un.org/en/development/desa/population/publications/pdf/urbanization/the_worlds_cities_in 2016_data_booklet.pdf.

Young, S.B. and A.T. Wells (2011), Airport Planning and Management, McGraw-Hill, New York.

Zografos, K.G. et al. (2013), “A Decision Support System for Integrated Airport Performance Assessment and Capacity Management”, in Zografos, K.G., G. Andreatta and A.R. Odoni (eds.) Modelling and Managing Airport Performance, John Wiley \& Sons, Chichester.

Zografos, K.G., M.A. Madas and K.N. Androutsopoulos (2017), "Increasing airport capacity utilisation through optimum slot scheduling: review of current developments and identification of future needs", Journal of Scheduling, Vol. 20/1, Springer, Berlin, pp. 3-24. 


\section{Annex I \\ List of Participants}

\section{International Experts}

\section{Barry HUMPHREYS}

Roundtable Chair

BKH Aviation

UK

\section{Nicole ADLER}

Professor

Hebrew University of Jerusalem

ISRAEL

\section{Roberto AGUERREBERE}

Head

Instituto Mexicano del Transporte

MEXICO

\section{Carlos AGUILAR}

Administrator

International Airport of Querétaro

MEXICO

\section{Hector Guillermo ARRIOLA CONSUEGRA}

Manager

Volaris

MEXICO

\section{Philippe AYOUN}

Regional Director, South of France, Toulouse

French Civil Aviation Authority, DGAC

FRANCE

\section{Stefano BARONCI}

Director of Economics

ACI World

CANADA

\section{Anne BERNARD}

Economic Counsellor (Conseillère économique)

French Embassy to Mexico

FRANCE 


\section{Elliott BLACK}

Director of Planning and Programming

Federal Aviation Administration

USA

\section{Geert BOOSTEN}

Head

Aviation Academy, Amsterdam University of Applied Sciences

NETHERLANDS

\section{Guillaume BURGHOUWT}

Head

SEO Amsterdam Economics

NETHERLANDS

\section{Jaime CALDERON}

Regional Officer, NACC

Aerodromes and Ground Aids,

ICAO

\section{Gustavo FLORES}

Asesor del Secretario de Comunicaciones y Transportes

Secretaría de Comunicaciones y Transportes

MEXICO

José Luis GARZA ÁLVAREZ

Director General

Interjet

MEXICO

\section{Gunter HEINRICH}

Senior Manager, Airport Slot Management

Frankfurt International Airport

GERMANY

\section{Alfonso HERRERA GARCÍA}

Aviation Expert

Instituto Mexicano del Transporte

MEXICO

\section{Alexandre JACQUILLAT}

Assistant Professor of Operations Research and Public Policy

Carnegie Mellon University

USA 


\section{MJ KIM}

Manger of External Relations

Incheon Airport

KOREA

\section{Roberto KOBEH GONZALEZ}

Director General

Servicios a la Navegación en el Espacio Aéreo Mexicano

MEXICO

\section{Sandra GONZÁLEZ NAVARRO}

Deputy Director of Planning and Evaluation

Grupo Aeroportuario de la Ciudad de México (GACM)

MEXICO

\section{Miguel MUJICA MOTA}

Associate Professor

Aviation Academy, Amsterdam University of Applied Sciences

NETHERLANDS

\section{Joao PITA}

Head of Airline Business

São Paulo-Guarulhos International Airport

BRAZIL

\section{Paul SMALE}

Advisor

Department for Transport

UK

\section{José Luis SUÁREZ DURÁN}

Gerente de operaciones

Volaris

MEXICO

\section{Iker URIONAGUENA}

Manager of Client Relations

Volaris

MEXICO

Mike TRETHEWAY

Senior Economist

InterVISTAS Consulting

CANADA 


\section{Victor VALDES}

Professor, School of Business and Economics

Anáhuac University

MEXICO

\section{James WILTSHIRE}

Head of Policy Analysis

IATA

SWITZERLAND

\section{Tina WONG}

Economic Officer

US Embassy to Mexico City

USA

\section{Brian ZACKON}

Independent Expert

CANADA

\section{Konstantinos ZOGRAFOS}

Distinguished Professor, Department of Management Science

Lancaster University Management School

UK

\section{Catya ZUÑIGA}

Associate Professor

Aeronautical University of Querétaro

MEXICO

\section{International Transport Forum at the OECD}

\section{Jagoda EGELAND}

Economist \& Project Manager

International Transport Forum, OECD

\section{Stephen PERKINS}

Head of Research and Policy Analysis

International Transport Forum, OECD 


\section{Notes}

\section{${ }^{1}$ See ANNEX I List of Participants}

${ }^{2}$ For more information and a definition of a WSG Level 3 airport, see: www.iata.org/policy/slots/Pages/slotguidelines.aspx

${ }^{3}$ For more details, see ITF (2014a)

${ }^{4}$ See Frontier Economics (2014) and PwC (2013)

${ }^{5}$ More details can be found in Herrera (2017) and Mujica et al. (2017)

${ }^{6}$ For more details, see www.nats.aero/discover/collaborative-decision-making/ and EUROCONTROL (2017)

${ }^{7}$ See www.eurocontrol.int/node/10666/library/cdm brochure.pdf

${ }^{8}$ For more information, see $\underline{w w w . s e s a r j u . e u /}$

${ }^{9}$ For more information, see www.faa.gov/nextgen/

${ }^{10}$ See NATS and SESAR (2017)

${ }^{11}$ See, for example, Zografos et al. (2013)

${ }^{12}$ For a more detailed overview of different policy levers see Burghouwt (2017), and for insights into advantages and disadvantages of how slots are allocated at congested airports in Europe and the USA, see Adler and Yazhemsky (2017).

${ }^{13}$ For more details, see https://www.sec.gov/Archives/edgar/data/4515/000119312515261937/d945812dex104.htm.

${ }^{14}$ Slot concentration in the hands of one carrier or alliance can provide passengers with higher frequencies and more available destinations. For a detailed explanation, see Burghouwt (2013).

${ }^{15}$ The FAA tracks flight operations closely at Level 2 airports: Chicago O'Hare International Airport in Illinois, Los Angeles International Airport, San Francisco International Airport in California, and Newark Liberty International Airport in New Jersey. At these airports carriers are expected to seek and obtain schedule approval from the FAA. Whilst this is done on a voluntary basis, if a carrier chooses to operate a flight without approval from the FAA and the airport becomes designated as Level 3, the carrier will not receive priority for any of the non-approved flights. This implies that in practice it is unlikely that all flights at Level 2 airports are completely freely scheduled by the carriers. Airlines may also need to consider whether there are any current or future airport infrastructure constraints as they plan flight times. More information is available here: www.faa.gov/about/office_org/headquarters_offices/ato/service_units/systemops/surface/slot_administra tion/schedule facilitation/.

${ }^{16}$ More details can be found in Burghouwt (2017).

${ }^{17}$ See Brueckner (2002, 2005), Mayer and Sinai (2003)

${ }^{18}$ See www.uk.reuters.com/article/china-airlines-slots-idUKL8N14K03M20151231 
${ }^{19}$ See Mott MacDonald (2006)

${ }^{20}$ European Commission (2008), Communication from the Commission to the European Parliament, the Council, the European Economic and Social Committee and the Committee of the Regions on the application of Regulation (EEC) No 95/93 on common rules for the allocation of slots at Community airports. See http://eur-lex.europa.eu/legal-content/EN/TXT/?uri=CELEX\%3A52008DC0227 
